Agreements, Belfer Center, 2016. http://www.belfercenter.org/sites/default/files/legacy/files/ 160700_horton-keith-honegger_vp2.pdf.

International Institute for Sustainable Development (IISD). "Earth Negotiation Bulletin." COP 21 Final 12, no. 663 (2015). http://www.iisd.ca/download/pdf/enb12663e.pdf.

Keohane, Robert O. and David G. Victor. "Cooperation and Discord in Global Climate Policy." Nature Climate Change 6, no. 6 (2016): 570-575.

Martin, Richard. "The Dubious Promise of Bioenergy Plus Carbon Capture." MIT Technology Review. January 8, 2016. https://www.technologyreview.com/s/544736/the-dubious-promise-of-bioenergyplus-carbon-capture/.

Parker, Andy and Oliver Geden. "No Fudging on Geoengineering." Nature Geoscience 9, no. 12 (2016): 859-860.

Rogelj, Joeri, Michel den Elzen, Niklas Höhne, Taryn Fransen, Hanna Fekete, Harald Winkler, Roberto Schaeffer, Fu Sha, Keywan Riahi, and Malte Meinshausen. "Paris Agreement Climate Proposals Need a Boost to Keep Warming well below $2^{\circ}$ C." Nature 534, no. 7609 (2016): 631-639.

"The Kigali Amendment to the Montreal Protocol: HFC Phase-down." OzonAction Fact Sheet, 2016. http://www.unep.org/ozonaction/Portals/105/documents/7809-e-Factsheet_Kigali_Amendment_to_ MP.pdf.

United Nations Framework Convention on Climate Change (UNFCCC). "Adoption of the Paris Agreement." FCCC/CP/2015/L.9. December 12, 2015. https://unfccc.int/resource/docs/2015/cop21/ eng/l09.pdf.

"Report of the Technical Review of the Sixth National Communication of Turkey." FCCC/IDR.6/ TUR. October 21, 2016. http://unfccc.int/resource/docs/2016/idr/tur06.pdf.

"Report of the Technical Review of a Joint First and Second Biennial Report of Turkey." FCCC/ TRR.2/TUR. October 14, 2016. http://unfccc.int/resource/docs/2016/trr/tur.pdf.

WBGU - German Advisory Council on Global Change. "Development and Justice through Transformation: The Four Big 'I's." Special Report. Berlin: WBGU, 2016.

Zelli, Fariborz and Harro van Asselt. "Fragmentation." In Research Handbook on Climate Governance. Edited by Karin Bäckstrand and Eva Lövbrand. Cheltenham: Edward Elgar, 2015. 121-131.

doi: $10.1017 / n p t .2017 .21$

\title{
Right here, right now: a call for engaged scholarship on climate justice in Turkey
}

\section{Ethemcan Turhan}

There are a few different issues that I would like to address and unfortunately not all of them can be treated in depth here; hopefully, though, they can open up some new discussions. Such beginnings, particularly if they can pave the way for more social science engagement with climate change in Turkey, might also

Ethemcan Turhan, Environmental Humanities Lab, KTH Royal Institute of Technology, SE-100 44, Stockholm, Sweden, ethemcan@kth.se. 
work towards resolving Turkey's problem with "precious loneliness," which has been well highlighted by Semra Cerit Mazlum's contribution above.

First of all, let us come to terms with the fact that engagement with climate change does not solely mean having access to climate finance. I believe this is a point we must keep in mind. Since 1992, and even before, one of the issues obstructing Turkey within the UNFCCC process has been the discussion on the reception and provision of financing. Yet the climate regime and the collective fight against climate change outside of the international process require something beyond such financial concerns. ${ }^{1} \mathrm{I}$ believe this is valid not only on a global scale, but even more so on a local scale. A novel approach that accords due attention to needs and capabilities is much needed at the national, sub-national, regional, and local levels. Moreover, action on climate change calls for a paradigm shift or, better, an all-out transformation, as the recent literature suggests. ${ }^{2}$ Such a transformation needs to be developed in dialogue with the natural sciences, economics, and the administrative sciences, as well as the social sciences and humanities, and I believe we will only be able to achieve such a transformation by merging a scientific inquiry that is attentive to climate with the notion of environmental justice. ${ }^{3}$

In this context, a few things need to be recalled. One of these is a point that is tirelessly repeated by Turkey at international negotiations, the story to the effect that, "in reality, our emissions are not that big of a deal." Somehow, for Turkish delegations, the main issue always boils down to this. Erinç Yeldan, in his contribution here, also discusses what our fair share is, but let us also remember some basics: there is a UNFCCC report on each country's current share in global emissions, published after the Paris Agreement produced at COP 21,4 and it shows that Turkey's share of global emissions amounts to 1.24 percent. In other words, Turkish state institutions' use of old figures like 0.7 or 0.89 percent is, if not an oft-committed mistake, at best misleading. This is exactly why we need a better policy, one informed by science, since we need to be able to evaluate policy alternatives using the correct figures on emissions and

1 Moreover, the argument that the main obstacle to Turkey's engagement with the new climate regime is its inability to access climate finance is rather misleading; see Arif Cem Gündoğan and Ethemcan Turhan, "Turkey: Notes from a State of (Climatic) Emergency," Climate Home, November 10, 2016. http://www.climatechangenews.com/2016/11/10/turkey-notes-from-a-state-ofclimatic-emergency/.

2 Karen L. O'Brien, "Climate Change and Social Transformations: Is It Time for a Quantum Leap?" WIREs Climate Change 7, no. 5 (2016): 618-626.

3 Julian Agyeman, David Schlosberg, Luke Craven, and Caitlin Matthews, "Trends and Directions in Environmental Justice: From Inequity to Everyday Life, Community, and Just Sustainabilities," Annual Review of Environment and Resources 41, no. 1 (2016): 321-340.

4 United Nations Framework Convention on Climate Change (UNFCCC), "Report of the Conference of the Parties on Its Twenty-first Session, Held in Paris from 30 November to 13 December 2015," FCCC/ CP/2015/10. http://unfccc.int/resource/docs/2015/cop21/eng/10.pdf. 
development indicators. As is frequently stated, Turkey may not be at the top of the list of global emitters, but we still need to underline the fact that it is not at the bottom, either. Therefore, lock-in to a single model of development which evades serious action on climate change needs to be avoided, and for this, again, we need better, more up-to-date, and more politically relevant climate science across the disciplines.

As mentioned in other contributions here, in early 2016 Turkey submitted its Sixth National Communication on Climate Change to the UNFCCC. ${ }^{5}$ This is effectively a taking of stock on the state of the art of national climate action-but when examined closely, it is easy to see that the bulk of the peer-reviewed scientific information in this communication comes from the country's First National Communication, published back in 2007. Thus, almost ten years on, the foundation of Turkey's national communications remains earlier scientific studies. This points to a very important shortcoming concerning the production of locally informed and relevant natural and social science in the field of climate change: in the absence of properly peer-reviewed scholarly works, climate change knowledge is left in the hands of a wave of civil society assessments, often supported by unchecked claims or reports prepared for internal use by state institutions.

In our review of the climate change policy literature in Turkey, ${ }^{6}$ while not necessarily claiming to be comprehensive, we observed that most publications on the topic were raw materials that had not been properly reviewed or interpreted. Some of these materials were even scientifically questionable. This is precisely why Turkey urgently needs to invest in climate change research and overcome the populism that is prevalent not only in the state, but also in some parts of civil society as well. Let me give a simple example relating to the connections between the Syrian crisis, climate change, and the 2007-2008 drought. References to the role of climate change in the onset of the Syrian war have often been made so as to attract attention or build awareness, since we are witnessing one of the most important waves of migration in history and so would often like to use it to bring climate change to the public agenda. Politicians want to use climate change as leverage just as development experts want to use it to ensure a constant flow of development aid. Yet when we delve into the scientific literature on causality and correlation in climate change and conflict, things start to get trickier. ${ }^{7}$ The argument that climate change unilaterally drives violent

5 Republic of Turkey Ministry of Environment and Urbanization, Sixth National Communication of Turkey under the UNFCCC, 2016. https://unfccc.int/files/national_reports/non-annex_i_natcom/application/ pdf/6_bildirim_eng_11_reducedfilesize.pdf.

6 Ethemcan Turhan, Semra Cerit Mazlum, Ümit Şahin, Alevgül H. Şorman, and A. Cem Gündoğan, "Beyond Special Circumstances: Climate Change Policy in Turkey 1992-2015," WIREs Climate Change 7, no. 3 (2016): 448-460.

7 See, e.g., Colin Kelley, Shahrzad Mohtadi, Mark A. Cane et al., "Climate Change in the Fertile Crescent and Implications of the Recent Syrian Drought," Proceedings of the National Academy of Sciences of the 
conflict is often misplaced, as it tends to obscure the pre-existing conditions that gave rise to vulnerabilities in the first place, such as the dismantling of social safety nets, the disintegration of rural areas through structural adjustment and depeasantization, ethnic/racial segregation, and so on. Climate change, drought, and other related phenomena contribute to already fragile social, economic, and historical vulnerabilities, adding insult to injury and increasing the risks in Syria just as much as in Turkey and elsewhere. ${ }^{8}$ Therefore, jumping to conclusions about a deterministic climatic catastrophism often do more harm than good in relation to trying to advance a progressive agenda on climate change, which in fact requires a rethinking of the root causes lying deeper down in the political economy. Thus, we need to come to terms with the fact that, in reality, neoliberal capitalism-together with its recently fashionable authoritarian variations-constitutes the root cause of many vulnerabilities in the face of a changing climate. In this context, we in Turkey also need to further study the gray area between scientific work on climate change and the role populism plays in engaging or disengaging public. ${ }^{9}$

I would also like to briefly touch upon another issue. In his contribution here, Erinç Yeldan mentions Pareto equilibrium, which reminds me of Schellnhuber et al.'s work on tipping points. ${ }^{10}$ In this piece, the authors put forward an interesting argument to the effect that, historically, there are particular tipping points in both biophysical and social systems, beyond which the system dynamics are fundamentally altered. Most of the time, one need not reach more than 50 percent of a given population to trigger such a tipping point: what is needed instead is a determined and critical mass of $15-25$ percent of a population committed to actualizing transformation. In this regard, understanding how the transformation to a low-carbon economy is made possible by energy democracy and climate justice ${ }^{11}$ requires attention in studies on Turkey as well. As in any other social struggle, once you reach critical mass yet keep upping the ambition, it means that you may well exceed that tipping point.

United States of America 112, no. 11 (2015): 3241-3246 on the deterministic relations between the Syrian war and climate change, and its rebuttal in Francesca de Châtel, "The Role of Drought and Climate Change in the Syrian Uprising: Untangling the Triggers of the Revolution," Middle Eastern Studies 50, no. 4 (2014): 521-535 and Christiane J. Fröhlich, "Climate Migrants as Protestors? Dispelling Misconceptions about Global Environmental Change in Pre-revolutionary Syria," Contemporary Levant 1, no. 1 (2016): 38-50.

8 Jesse Ribot, "Cause and Response: Vulnerability and Climate in the Anthropocene," Journal of Peasant Studies 41, no. 5 (2014): 667-705.

9 See also Mehmet Ali Üzelgün and Paula Castro, "The Voice of Science on Climate Change in the Mainstream Turkish Press," Environmental Communication 8, no. 3 (2014): 326-344.

10 Hans Joachim Schellnhuber, Stefan Rahmstorf, and Ricarda Winkelmann, "Why the Right Climate Target Was Agreed in Paris," Nature Climate Change 6, no. 7 (2016): 649-653.

11 See the emerging body of work on energy democracy and climate justice in Turkey at www. iklimadaleti.org. 
What, then, does exceeding the tipping point mean for climate politics in the Turkish context? It means that, if we are serious about the $2^{\circ}$ or even $1.5^{\circ} \mathrm{C}$ commitment of the Paris Agreement ${ }^{12}$ (which Turkey has yet to ratify), we urgently need to end our dependence on fossil fuels and deeply question the inexorable economic growth paradigm. ${ }^{13}$ This implies both a transformation in the well-critiqued politics of agriculture, urbanization, mining, and energy, ${ }^{14}$ and directing attention toward a new politics of climate change adaptation in Turkey. ${ }^{15}$ In this context, environmental conflicts can be used as an opportunity to repoliticize development policy so as to move beyond the deadlock of modernization and technocracy. But what does this mean in practice? One of the best examples of such practices can be found in the anti-coal movement spreading through Turkey. As coal, the prime source of energy-related emissions, becomes Turkey's strategic choice for energy expansion in the near future, ${ }^{16}$ environmental victories like that at Gerze against a major coal-fired power plant build hope about linking questions of global climate justice politics up with local environmental concerns. ${ }^{17}$ Studying the politics and dynamics of such grassroots contestations to Turkey's preventable carbon lock-in needs to be at the top of our research agendas.

Finally, it might be pointed out that, in Turkey, one often gets caught up in local issues to the point of missing the bigger picture. The risks posed by

12 The Global Carbon Budget 2016 report estimates that global emissions will peak between 2020 and 2030 and rapidly and cumulatively decline thereafter to meet these targets; see Corinne Le Quéré, Robbie M. Andrew, Josep G. Canadell et al. "Global Carbon Budget 2016," Earth System Science Data 8 (2016): 605-649. doi:10.5194/essd-8-605-2016.

13 Viviana Asara, lago Otero, Federico Demaria, and Esteve Corbera, "Socially Sustainable Degrowth as a Social-Ecological Transformation: Repoliticizing Sustainability," Sustainability Science 10, no. 3 (2015): 375-384.

14 Çağlar Keyder and Zafer Yenal, Bildiğimiz Tarımın Sonu: Küresel iktidar ve Köylülük (İstanbul: İletişim Yayınları, 2013); Bengi Akbulut and Ayfer Bartu Candan, "Bir-Iki Ağacın Ötesinde: İstanbul'a Politik Ekoloji Çerçevesinden Bakmak," in Yeni Istanbul Çalışmaları: Sınırlar, Mücadeleler, Açılımlar, ed. Cenk Özbay and Ayfer Bartu Candan (İstanbul: Metis Yayınları, 2014): 283-300.; and Begüm Özkaynak, Cem İskender Aydın, Pınar Ertör-Akyazı, and Irmak Ertör, "The Gezi Park Resistance from an Environmental Justice and Social Metabolism Perspective," Capitalism Nature Socialism 26, no. 1 (2015): 99-114.

15 Rana I. Connelly and Pınar G. Bal, "Local Networks of Resilience and Climate Adaptation: The Case of İstanbul," in Climate Change Adaptation, Resilience and Hazards, ed. Walter Leal Filho, Haruna Musa, Gina Cavan, Paul O'Hare, and Julia Seixas (Switzerland: Springer, 2016): 109-123 and Ethemcan Turhan, "Value-based Adaptation to Climate Change and Divergent Developmentalisms in Turkish Agriculture," Ecological Economics 121 (2016): 140-148.

16 Ümit Şahin, "Warming a Frozen Policy: Challenges to Turkey's Climate Politics after Paris," Turkish Policy Quarterly 15, no. 2 (2016): 117-129.

17 See also Murat Arsel, Bengi Akbulut, and Fikret Adaman, "Environmentalism of the Malcontent: Anatomy of an Anti-coal Power Plant Struggle in Turkey," Journal of Peasant Studies 42, no. 2 (2015): 371-395. 
negative emission technologies and the commodification of natural assets through carbon markets, mentioned by Yeldan and Cerit Mazlum in their contributions here, represent just two dimensions of this big-and grimpicture. The environmental social sciences dealing with Turkey also arguably suffer from the same myopia. And last but not least, Turkey's repeated attempts to host the UNFCCC negotiations in 2020, without even expressing the intention to ratify the Paris Agreement, presents a curious case. Personally, I have serious doubts about the viability of and actual contribution such offers might make to advance global climate governance, beyond just whitewashing a foreign policy that is in tatters. This calls for further critical engagement on climate politics from scholars of international relations, political science, environmental history, sociology, and anthropology (among others) in Turkey. In conclusion, I very much doubt that a climate policy that does not essentially interact with either non-state actors or academia has any chance of success, whether nationally or internationally. Turkey still does possess a window of opportunity, however small, to transform its position in the global efforts to combat climate change and move toward a true low-carbon economy domestically by setting a peak for its emissions in the foreseeable future. This will inevitably require an understanding of the costs of inaction on climate change in a world that is moving rapidly toward populist post-fact regimes. It also calls for intense exploration of the social and economic costs of taking action toward deep decarbonization. Here, the social sciences and humanities have a crucial role to play in pushing Turkey's climate policy toward a more progressive, constructive, and fair position.

\section{References}

Agyeman, Julian, David Schlosberg, Luke Craven, and Caitlin Matthews. "Trends and Directions in Environmental Justice: From Inequity to Everyday Life, Community, and Just Sustainabilities." Annual Review of Environment and Resources 41, no. 1 (2016): 321-340.

Akbulut, Bengi and Ayfer Bartu Candan. "Bir-iki Ağacın Ötesinde: İstanbul'a Politik Ekoloji Çerçevesinden Bakmak." In Yeni İstanbul Çalışmaları: Sınırlar, Mücadeleler, Açılımlar. Edited by Cenk Özbay and Ayfer Bartu Candan. İstanbul: Metis Yayınları, 2014. 283-300.

Arsel, Murat, Bengi Akbulut, and Fikret Adaman. "Environmentalism of the Malcontent: Anatomy of an Anti-coal Power Plant Struggle in Turkey." Journal of Peasant Studies 42, no. 2 (2015): 371-395.

Asara, Viviana, lago Otero, Federico Demaria, and Esteve Corbera. "Socially Sustainable Degrowth as a Social-Ecological Transformation: Repoliticizing Sustainability." Sustainability Science 10, no. 3 (2015): 375-384.

Châtel, Francesca de. "The Role of Drought and Climate Change in the Syrian Uprising: Untangling the Triggers of the Revolution." Middle Eastern Studies 50, no. 4 (2014): 521-535.

Connelly, Rana I. and Pınar G. Bal. "Local Networks of Resilience and Climate Adaptation: The Case of İstanbul." In Climate Change Adaptation, Resilience and Hazards. Edited by Walter Leal Filho, Haruna Musa, Gina Cavan, Paul O'Hare, and Julia Seixas. Switzerland: Springer, 2016. 109-123. 
Fröhlich, Christiane J. "Climate Migrants as Protestors? Dispelling Misconceptions about Global Environmental Change in Pre-revolutionary Syria." Contemporary Levant 1, no. 1 (2016): 38-50.

Gündoğan, Arif Cem and Ethemcan Turhan. "Turkey: Notes from a State of (Climatic) Emergency." Climate Home. November 10, 2016. http://www.climatechangenews.com/2016/11/10/turkey-notesfrom-a-state-of-climatic-emergency/.

Kelley, Colin P., Shahrzad Mohtadi, Mark A. Cane, Richard Seager, and Yochanan Kushnir. "Climate Change in the Fertile Crescent and Implications of the Recent Syrian Drought." Proceedings of the National Academy of Sciences of the United States of America 112, no. 11 (2015): 3241-3246.

Keyder, Çağlar and Zafer Yenal. Bildiğimiz Tarımın Sonu: Küresel İktidar ve Köylülük. İstanbul: İletişim Yayınları, 2013.

O'Brien, Karen L. "Climate Change and Social Transformations: Is It Time for a Quantum Leap?" WIREs Climate Change 7, no. 5 (2016): 618-626.

Özkaynak, Begüm, Cem İskender Aydın, Pınar Ertör-Akyazı, and Irmak Ertör. "The Gezi Park Resistance from an Environmental Justice and Social Metabolism Perspective." Capitalism Nature Socialism 26, no. 1 (2015): 99-114.

Quéré, Corinne Le, Robbie M. Andrew, Josep G. Canadell, Stephen Sitch, Jan Ivar Korsbakken, Glen P. Peters, Andrew C. Manning, Thomas A. Boden, Pieter P. Tans, Richard A. Houghton, Ralph F. Keeling, Simone Alin, Oliver D. Andrews, Peter Anthoni, Leticia Barbero, Laurent Bopp, Frédéric Chevallier, Louise P. Chini, Philippe Ciais, Kim Currie, Christine Delire, Scott C. Doney, Pierre Friedlingstein, Thanos Gkritzalis, Ian Harris, Judith Hauck, Vanessa Haverd, Mario Hoppema, Kees Klein Goldewijk, Atul K. Jain, Etsushi Kato, Arne Körtzinger, Peter Landschützer, Nathalie Lefèvre, Andrew Lenton, Sebastian Lienert, Danica Lombardozzi, Joe R. Melton, Nicolas Metzl, Frank Millero, Pedro M.S. Monteiro, David R. Munro, Julia E.M.S. Nabel, Shin-ichiro Nakaoka, Kevin O'Brien, Are Olsen, Abdirahman M. Omar, Tsuneo Ono, Denis Pierrot, Benjamin Poulter, Christian Rödenbeck, Joe Salisbury, Ute Schuster, Jörg Schwinger, Roland Séférian, Ingunn Skjelvan, Benjamin D. Stocker, Adrienne J. Sutton, Taro Takahashi, Hanqin Tian, Bronte Tilbrook, Ingrid T. van der Laan-Luijkx, Guido R. van der Werf, Nicolas Viovy, Anthony P. Walker, Andrew J. Wiltshire, and Sönke Zaehle. "Global Carbon Budget 2016." Earth System Science Data 8 (2016): 605-649. doi: 10.5194/essd-8605-2016.

Republic of Turkey Ministry of Environment and Urbanization. Sixth National Communication of Turkey under the UNFCCC. 2016. https://unfccc.int/files/national_reports/non-annex_i_natcom/application/ pdf/6_bildirim_eng_11_reducedfilesize.pdf.

Ribot, Jesse. "Cause and Response: Vulnerability and Climate in the Anthropocene." Journal of Peasant Studies 41, no. 5 (2014): 667-705.

Schellnhuber, Hans Joachim, Stefan Rahmstorf, and Ricarda Winkelmann. "Why the Right Climate Target Was Agreed in Paris." Nature Climate Change 6, no. 7 (2016): 649-653.

Seto, Karen C., Steven J. Davis, Ronald B. Mitchell, Eleanor C. Stokes, Gregory Unruh, and Diana Ürge-Vorsatz. "Carbon Lock-in: Types, Causes, and Policy Implications." Annual Review of Environment and Resources 41 (2016): 425-452.

Şahin, Ümit. "Warming a Frozen Policy: Challenges to Turkey's Climate Politics after Paris." Turkish Policy Quarterly 15, no. 2 (2016): 117-129.

Turhan, Ethemcan. "Value-based Adaptation to Climate Change and Divergent Developmentalisms in Turkish Agriculture." Ecological Economics 121 (2016): 140-148.

Turhan, Ethemcan, Semra Cerit Mazlum, Ümit Şahin, Alevgül H. Şorman, and A. Cem Gündoğan. "Beyond Special Circumstances: Climate Change Policy in Turkey 1992-2015." WIREs Climate Change 7, no. 3 (2016): 448-460.

United Nations Framework Convention on Climate Change (UNFCCC). "Report of the Conference of the Parties on Its Twenty-first Session, Held in Paris from 30 November to 13 December 2015." FCCC/ CP/2015/10. http://unfccc.int/resource/docs/2015/cop21/eng/10.pdf.

Üzelgün, Mehmet Ali and Paula Castro. "The Voice of Science on Climate Change in the Mainstream Turkish Press." Environmental Communication 8, no. 3 (2014): 326-344. 